Article

\title{
Company fundamentals and stock price movements: The role of crude oil prices - Evidence from Nigerian Stock Exchange (NSE)
}

\author{
Tijani Bashir Musa ${ }^{1 *}$ \\ 1 Department of Banking \& Finance, Ahmadu Bello University, Zaria, Nigeria; dokaje@yahoo.com \\ * Correspondence: dokaje@yahoo.com, +238033472659
}

\begin{abstract}
This study analyzed company fundamentals on how it relates and predict stock price movements and the extent of the role of oil prices in moderating the influence of these company fundamentals in stock price movements. The study covered the period of 2014 to 2018. The study is a panel study. A total of 132 companies were sampled from 196 companies listed on the Nigerian Stock Exchange (NSE) as of December 2018. Data were collected from a secondary source. Multiple linear regression models were used to analyze the data. The study found that a relationship exists between selected companies' fundamentals and stock prices, and oil prices moderate the relationship. But EPS and Working Capital have high predictive power on stock price movements but moderating with oil prices the influence reduces significantly. The study recommends among others that Managers of companies in Nigeria should formulate policies and exert effort geared towards improving company fundamentals in the event of oil prices increases.
\end{abstract}

Keywords: Return on Asset (ROA); Return on Equity (ROE); Earning Per Share (EPS); Profit; Working Capital; Company Fundamental.

JEL codes: G10, G12, G30.

\section{Introduction}

The primary goal or objective of a company should be to maximize the value or prices of the company's stock. The success or failure of management's decisions can be evaluated only in light of the impact of company stock prices (Remi, 2005). The company's stock prices have direct purview in managerial efficiency which is one of the good signals of the company's fundamentals. The company fundamental can be determined by external factors (such as crude oil price, the aggregate supply of money, interest rate, inflation, exchange rate among others) or internal factors (firm-specific such as firm earning, inventory management, dividend, price-Earnings ratios among others). The external factors are beyond the control of the company and are generally economy-wide. While the internal factors are under the control of the company. This internal factor is the approach of Fundamentalist as relating to Stock Price movements. Both the internal and external factors directly or impliedly affect stock prices as they also affect company fundamentals. Crude oil serves as a major source of energy in the global economy. The cost of crude oil as it spelled out in its prices relates to global companies that translate into the fundamentals of these companies. Jones \& Kaul (1996) indicated that the oil price movement had a negative relationship with stock prices. This conclusion is rooted in the fact that rising in crude oil prices is associated with a rise in energy costs which is the center of the cost of production. The rise in the cost of production results in a decrease in the company profit which to a large extent may have negative repercussions on the value of the company. Nigeria is one of the oil-exporting countries with low manufacturing. Rising crude oil price increase revenue which stimulates aggregate demand and investment in Nigeria. Sauter \& Awerbuch (2003) posit that a rise in oil prices leads to a 
decrease in economic activities. This will decrease company performance. Jacobsen \& Maat (2003) argue that changes in oil prices strongly predict future stock market returns and hence, stock prices.

Thus, the arguments on whether company fundamentals have any predictive power on stock prices are not very clear in financial literature. Gompers, Ishii \& Metrick, (2003) believe that company fundamentals have predictive power on stock prices. This argument holds the view that operating efficiency, profitability, Return on Asset (ROA), Return on Equity (ROE), Return on Investment (ROI), Price - Earnings ratio (P/E ratio), sound working capital efficiency, and earnings influence the stock price.

In contrast, other researchers argue that company fundamentals do not determine stock prices. For example, Kopcke (2010) reports that since 1982, stock prices in New England have more than tripled, while the operating income of corporations has risen by less than one half. From 1997-2000, prices have increased by more than one half, while earning has fallen. In January 2010 the price of equity for a standard and poor composite of 500 stocks exceeded 23 times earnings, a comparatively high multiple by historical standard. The price of the stock fell 17 times earnings in the late 1970s. From this argument fundamentals of corporations did not cause stock prices to increase but to decrease. These negate the fundamentalist approach. Stock prices here are not directly determined by earning and other company fundamentals measures but they are directly determined by the balance between the demand for and supply of firm stock. Demand and supply cause stock prices to fluctuate.

In Nigeria, the relationship between company fundamentals and stock prices is also ambiguous. Some firms' are not even in operation, while others are at the edge of collapse, but their share prices are increasing (SEC, 2007). Bashir (2015) Conducted a panel study on 140 companies quoted on the Nigeria Stock Exchange, the study found that company fundamental parameters have predictive power on stock price movements (operating efficiency). Besides, Bashir (2019) established that some company fundamentals (specifically earning per share and working capital) have predictive power to stock price movements. This study intends to investigate whether the introduction of crude oil prices as an external factor could modify the relationship between company fundamentals and Stock price movements in Nigeria.

The study attempts to answer the following questions:

- To what extent do company fundamentals relate to stock price movements in Nigeria?

- In what ways do company fundamentals predict stock price movements in Nigeria?

- Can crude oil prices modify the predictive power of company fundamentals on stock price movements in Nigeria?

The major objective of the study is to examine the moderating effect of Crude oil prices on the predictive power of company fundamentals on stock price movements in Nigeria. The specific objectives are to:

- Find out the extent of the relationship between company fundamentals and Stock price movements in Nigeria.

- To identify the ways company fundamentals, predict Stock price movements in Nigeria.

- To establish whether crude oil prices could modify the predictive power of company fundamentals on the Stock price movement in Nigeria.

To achieve the above objectives the following hypotheses were formulated thus:

$\mathrm{H}_{1}$ : Company fundamentals have no significant relationship with Stock Price movements in Nigeria.

$\mathrm{H}_{2}$ : Company fundamentals have no predictive power on Stock Price movements in Nigeria.

$\mathrm{H}_{3}$ : Crude oil prices do not moderate the predictive power of company fundamentals on Stock Price movements in Nigeria.

The company fundamental in the context of this study is measured by ROA, ROE, EPS, PROFIT, and WORKING CAPITAL. While the stock price movements are the changes in the value of stock prices throughout the study. 
This study is expected to reveal whether crude could moderate the predictive power of company fundamentals on stock price movements. If the predictive power is established, it would assist prospective investors to know the criteria to be used in channeling their investment fund to the right portfolio in their quest for investment, Nigerian company would identify which of the company fundamentals affect stock price movements and at what level of crude oil price. The study covers the period from 2014 to 2018. The period of the study is chosen because it was the period when the Nigerian Stock Market in particular is experienced a serious downturn due to the economic recession in Nigeria caused by a drastic fall in crude oil prices. Reasons could easily be seen and understood from Nigerian companies fundamental and the performance of Nigerian stock exchange. This study focuses on the predictive power of companies fundamental on Stock Price movements; the role of crude oil price.

Because of the on-going difficulties in obtaining data from private organizations, due to the fear that competitors will get access to the data, the study fully relied only on secondary data published by Nigerian Stock Exchange (NSE), Securities and Exchange Commission (SEC), and Nigerian Deposit Insurance Corporation (NDIC). To mitigate the influence of this limitation on the quality of the findings of this research, the study compared data obtained from the companies with the ones obtained from regulatory authorities such as SEC, NSE, and NDIC to ensure equality and reliability of the data. Where discrepancies exist, such data is discarded.

\section{Review of Related Literature and Theoretical Framework}

A company is a legal entity which can sued or be sued, and exist for a purpose (Richardson, 2000). Company performance is a difficult concept, both in terms of definition and measurement (Keats \& Hitt, 2000). The objective measure is both accounting-based operating performance and market-based performance are used. A financial analyst and investors need certain yardsticks to evaluate the financial condition and performance of a company. These yardsticks to measure performances are company fundamentals. These company fundamentals comprise of Return on Asset (ROA), Return on Equity (ROE), Profit, earning per share (EPS), and Working Capital.

According to Van Horne \& Wachowicz (2009), Working capital may be seen as capital invested in the current asset. The current asset is that asset that can easily be converted into cash within a short period. Profit is the difference between price and the cost of bringing to market whatever it is accounted as an enterprise in terms of the component costs of delivered goods/services and any other expenses (Salami, 1999). The debate of Cleveland (2012) on ROA broadens the monetary value as a means of relating Assets with profitability. He views ROA as a measure of the amount of gain a company is relative to its Total Assets. Clark (2013) sees ROE as a measure of the profitability of a company based on the money it had to work with. ROE measures a company's profit as a percentage of the combined equity of all ownership interest in the company. EPS according to Higgin (2010) is a company profit divided by its number of common outstanding shares. Stock prices are seen as the value attached to each equity in a given period, which may and may not be as a result of information asymmetric (Fama, 1970).

The studies conducted by Shiller (2000), Fama \& French (2002) indicate the extent to which how company fundamentals predict stock price movements. Both studies use regressions of stock returns on the lagged dividend and earnings yield on a pooled data of 25 companies quoted on the New York Exchange (NYE). They conclude that both endogenous variables have explanatory power to stock price movements. In the same vein, Bashir (2015) cited Chang \& Wang (2008) conducted a study using the Ohlson (1995) model on 100 Taiwan companies in 2004. The result indicates that the company's stock price movements have a positive significant relationship with the company's earnings. Ball \& Brown (2001) conducted a study to investigate the annual association between annual changes in stock prices and annual changes in earnings. The results obtained show that annual changes in stock prices cause earnings to change the following year. This could rarely occur at the firm level but could be true at the individual investor. The return of an investor is stock price appreciation plus dividend. This issue further reiterated. 
A similar study was conducted by Shiller (2000) argues that share prices can be viewed as predictions of investors earning. Therefore, it is reasonable that the variation in prices should not be greater than the variation in earnings. Shiller's position has been investigated thoroughly and reaches no agreement on the results. Bulkley \& Tonke (2001) criticize the position because the variable is constructed with hindsight (after its occurrence). It assumes that investors know the future that is what the dividend payments are going to be. When Bulkley \& Tonke (2001) adjust the test, so that the actual present value of the dividend is based on the information available at the time, then the excess volatility falls substantially. However, this effectively means that the excess volatility is because markets cannot be forecast accurately. Harasty \& Roulet (2000) worked on 17 developed countries and showed that stock prices are co-integrated with earnings (a proxy for dividends) and the long term firm performances in each country (except the Italian market, the short term company fundamentals ware used). Spyrou (2001) also studies the relationship between company fundamentals and stock prices but for the emerging economy of Greece. He finds that company fundamentals are negatively related, but only up to 1995 after which the relationship became insignificant.

One can observe that the relationship between company fundamentals and stock price could not be concluded, varying studies with different methods and data from different countries give contradictory results. To conclude whether profit has any predictive power on stock prices could be misleading.

According to Bahmani- Oskooee \& Sohrabian (1992) and Granger, Huang \& Yang (2000), there are sufficient theoretical reasons for causality to run in both directions between working capital efficiency and stock price. Abdulrasheed (2002) \& Stavarek (2004) argue that there is no theoretical consensus on the existence of the relationship between stock prices and working capital efficiency or on the direction of the relationship. According to Stavarek (2004) and Azman -Saini, Habibullah, Lawsiong \& Dayang-Afizzah (2006) mutual relations between stock prices and the working capital efficiency have attracted much attention of researchers and academics since the beginning of the 1990s.

In contrast, a positive relationship between stock price and the working capital efficiency with the direction of causation running from working capital efficiency to stock prices is also expected. Solnik (2000) use multivariate analysis on working capital efficiency and stock price collected from 120 companies across (Japan, U.S, Hong Kong, France, Germany, Britain, China, and the Netherlands) from 1989 to 1999 and found no significant effects of working capital efficiency on stock prices in industrialized countries. Hennigan \& Soenen (2008) reports strong negative interaction between working capital and stock price movements using monthly data of the U.S stock market index. This may be true because liquidity level does not account at all times in the performance of firms in the developed world.

In line with the above argument, Milosevic \& Milenko (2017) find that variables such as the size of the company measured by an asset, return on asset, leverage, earnings per stock book value, and price to book ratio provide a unique contribution to a statistically significant predictor of stock prices. Puspitaningtya (2017) concluded that financial performance measures only market valuation variables that significantly influence stock prices. variables such as liquidity, profitability, and growth do not affect stock price movements.

The relationship between a company's stock price movements and its operating efficiency has also been a subject of considerable research interest in recent years but results are also inconclusive. Bashir (2014) cited Lam (2006), Shiller (2000), Fama \& French (2002), and Sivakumar \& Waymire (2000) both use cointegration in an attempt to find out the extent of the relationship between operating efficiency and stock price movements. They concluded that the company's operating efficiency can explain a significant portion of the stock price movements. Cointegration techniques have a certain level of ability in measuring long term relation, but Lev (2001) conduct a review of several studies on the information contents. He finds that operating efficiency is not significantly related to contemporaneous stock prices.

Dehuan \& Zhenhu (2008) conduct a study on the Chinese stock market to determine whether and to what extent stock prices in the Chinese Stock Market are driven by companies operating 
efficiency. Samples of 10\% of most performing companies listed in the shanghais Stock exchange from 1996 to 2000 in terms of annual returns were examined. Simple and Multiple regressions were deployed to determine, at the company level, whether and to what extent these variables are related to stock price changes and what portion of the stock price movements can be explained by these company fundamentals. The results indicate that while company fundamentals have some explanatory power to stock price changes in the first two years during the testing period, the operating efficiency measures explanatory power of the stock price movements generally declined as the stock prices went up. The short-run response of firm operating efficiency to predict stock price movement is higher. The finding of Loughran \& Ritter (2003) is consistent with the finding of Hansen \& Crutchley (2006) in their attempt to find out whether operating efficiency could be used to forecast price movement. All the finding agrees that poor operating efficiency could be used to forecast stock prices movements.

From above it is observed that the relationship of operating efficiency with stock prices is inconclusive. The result of the study conducted in Dhaka differs from Bogota and that of China. This may imply that countries and the market relationship may be important when conducting a study of this nature.

Oliver (2015) Investigate the effects, magnitude, strength, causalities, and cointegration of the relationship between Banks Financial Performance Indicators and Share Prices in Nigeria banking sector, The nature and magnitude of the association between the dependent variable (MPS) and the independent variables Bank Age, Earnings Per Share (EPS) and Return on Assets (ROA) were determined using the multiple regression model. Granger causality procedure was applied to determine causalities while the Johansen Cointegration test was administered to verify the sustainability of the short-run relationships. It was found that only EPS, amongst the other variables, has both a positive and significant relationship with MPS. About $33 \%$ of the variations in the market price of ordinary shares could be explained by changes in earnings per share, returns on assets, and the age of the banks and there is a fairly strong relationship between MPS and earnings per share $(55 \%)$. There is a unidirectional Granger causality running from market price to earnings per share and a bidirectional Granger causality running from return on assets to earnings per share and from earnings per share to return on assets. These findings still maintain the prior expectation about the relationship and predictive power of company fundamentals on stock price movement.

Rentschler (2013) posits that the impacts of sudden changes in oil prices can have detrimental effects and repercussions on economic indicators such as employment, trade balance, inflation, and public accounts as well as stock market prices and exchange rates. In the same vein, Arouri, Lahiani, and Nguyen (2011) investigate the six countries members of the Gulf Cooperation Council (GCC) from 2005 - 2010, the find the existence of significant return and volatility spillovers between world oil prices and GCC stock markets. Basher and Sadorsky (2006) investigate the relationship between the oil price risk and stock market returns in 21 emerging stock markets and find strong evidence that oil price risk impacts stock prices in emerging markets. Shaharudin, Samad, and Bhat (2009) examine the effect of oil price movements on the stock price of oil and gas companies in the Us, India, and the UK. The study revealed the existence of a significant short-run and long-run relationship between oil prices and the oil stock. Also, they find that oil price volatility transmission has a persistent effect on the volatility of the stocks of the oil companies in all the countries.

This Study builds its argument upon Agency theory, Agency theory constructs a link between Agents and the Principal. The Primary agency relationships in business are those between the stockholder and Managers and between debt holders and stockholders as defined in Capital Structure. In establishing the relationship between company fundamentals and stock prices, it involves relating stockholders and managers or stockholders as principals and manager as an agent. This study builds the arguments as to whether manager efforts (company fundamentals) can result in maximization of a shareholders' wealth. Can a stockholder's interest be taken care of by a manager's performance? 


\section{Research Methodology}

The design for this study is the Panel (Longitudinal) research design. The Panel design is selected because the study has to do with the collection of data from across a large population and at a different point in time. The Panel designed is suitable for this study because quoted Nigerian Firms have similar characteristics and behavior in the Nigerian Stock Exchange. A stratified random sampling technique was used in the selection of the most performing companies, most performing stocks, and companies with low stock performance and companies with low performance. The most and least performing companies are determined by profit after tax divided by total assets, the higher the relationship the better. The most and least performing stocks are defined in terms of the volume of traded stocks in a year. This method takes into cognizance the identified characteristics or subcultures relevant to the study. This means that a company has the chance to appear in more than one stratum. A company may not also appear in either of the strata depending on the characteristic of the company about the stratum. But where a company appears in more than one stratum for the year, only one is considered.

The sample size was statistically determined using Yamane (1967) formula for a finite population as adopted in this study. Since the population of this study total of 196 companies in 31 sectors, then the sample size can be determined with the following formula;

$$
\mathrm{n}=\mathrm{N} / 1+\mathrm{N}(\mathrm{e}) 2
$$

Where $\mathrm{n}$ is the sample size, $\mathrm{N}$ is the finite population and e is the level of significance.

Given a population of 196 firms, at a 5\%-degree level of confidence, the sample size is 132 companies. This sample size is divided into four stratums. The strata constituted 25 percent of topperforming stock prices, 25 percent of the least performing stock prices, 25 percent of highestperforming companies, and 25 percent of the least performing companies. These strata comprise 33 companies from each stratum of the most performing companies, the most performing stock, the least performing companies, and the least performing stocks.

All data were collected from Secondary sources. The data for ROA, ROE, EPS, PROFIT, and WORKING CAPITAL were collected from the Fact Book of NSE. The data for stock prices were also collected from NSE, while the oil prices were collected from CBN statistical bulletin.

For our analysis, a multiple regression model was employed. The multiple regression was used to analyze the group companies' fundamentals metrics influence and their contribution to stock price movements and Crude oil Price as a moderator. A statistical/econometrics package Stata version 13 was used to analyze the data. The regression model was employed by Dehuan and Zhenhu (2008), and Bashir (2015) successfully to determine at the Company level whether and to what extent operating efficiency related to stock price movements in Chinese and Nigeria stock market and the portion of stock price movements that could be explained by the operating efficiency. This justifies the application of the study model to regress stock prices with company fundamentals.

Now, consider the relationship between company fundamentals and stock price under pooled ordinary Least Square (OLS) multiple regressions as follows;

StockPrici $=\alpha+\beta 1$ roai $+\beta 2$ roei $+\beta 3$ epsi $+\beta 4$ Profii $+\beta 5$ WorkCapi

Where $\beta_{1}, \beta_{2}, \beta_{3}, \beta_{4}$, and $\beta_{5}$ are regression parameters which are defined as the coefficient of the selected companies' indicators. roai, roe $\mathrm{i}_{\mathrm{i}}$ Profil, epshi, and WorkCapi are company fundamentals of $\mathrm{i}$ company. Stockpric is the average Stock Price that is the sum of stock price divided by the number of trading dates. roai is the return on asset, roei return on equity. Where roa $=$ Net income/ average total asset, roe $=$ Net income/ Net worth. Profii is the company profit which is defined as price- unit cost or total revenue - total cost. epsi is the company earning per share ratio which is defined as the number of company shares concerning its earnings. WorkCapi is the company working capital which is defined as Current Asset - Current liability and $\boldsymbol{\alpha}$ is the constant of the model.

The relationship between company fundamentals and stock prices is investigated. First, we explore the degree to which stock prices respond to company fundamentals. If the stock price moves with company fundamentals, then the stock prices follow the mean- reversion process; it means prices 
respond to the value of the intrinsic assets of the company. If the stock prices follow the mean reversion process, we should have a static and dynamic regression model, the former explains the short run relationship between company fundamentals and stock prices. While the latter would explain a long run relationship even when event and time impacted the variables. The model with the future response is;

$$
\text { StockPric }=\beta_{0}+\beta_{1 \text { roat }-1}+\beta_{2} \text { roet }-2_{2}+\beta_{3} \text { Profit }-3_{-3}+\beta_{4} \text { Earnpsh }_{\mathrm{t}-4}+\beta_{5} \text { WorkCap }_{\mathrm{t}-5}
$$

This is one way to model the dynamic response to include lagged values of company fundamentals on the right-hand side of the model; this is the basis of the distributed lag model in which a series of lagged explanatory variables account for the time adjustment process. Now consider the relationship between company fundamentals and stock prices as follows;

StockPricit $=\beta 0+\beta 1$ roeit $1+\beta 2$ roeit $2+\beta 3$ Profitit $3+\beta 4$ epsit $4+\beta 5$ WorkCapit $5+\mu$ it

Here $\mu_{i t}$ is normally distributed error - terms with zero expected mean, constant variance, no cross-sectional variation and time series correlation, and no autocorrelation. The independent variables are for $\mathbf{i}$ company at $\mathbf{t}$ time. The model is a benchmark in the value relevance studies firstly proposed by Ball and Brown (1998). The slope coefficient $\beta$ is called the company's fundamental response coefficient.

Kao and Chiang (2000) proposed the asymptotic distributions for the Ordinary Least Square (OLS), adjusted OLS, and dynamic OLS (DOLS) estimators. They used OLS, adjusted OLS, and DOLS estimators to calculate estimated Regression Coefficients (ERCS). They find that the OLS and adjusted OLS estimators have non-negligible biases in finite samples. Fixed effect regression may be more promising than an OLS estimator in estimating the Co-integrated panel regressions. This is further confirmed by the heteroskedasticity test of Breusch-Pagan/Cook Weisberg which revealed constant variance in the cross-section. However, fixed effects regressions proposed by Kao and Chiang (2000) rarely remain adequate estimator with the alternative hypothesis of heterogeneous samples in pooled regression. Pedroni $(2000,2001)$ proposed a random effect regression on pooled regression as a better estimator. This study derived its strength from Pedroni $(2000,2001)$.

The model of random effects pooled regression is as follows;

StockPricij $=\beta 0+\beta 1$ roa1ij $+\beta 2$ roe2ij $+\beta 3$ Profi3ij $+\beta 4$ eps $4 \mathrm{ij}+\beta 5$ WorkCap5ij $+(\alpha \mathrm{i}+\mu \mathrm{ij})$

To introduce moderator oil price the model thus:

StockPricij $=\beta 0+\beta 1$ roaOilPrice1ij $+\beta 2$ roeOilPrice $2 \mathrm{ij}+\beta 3$ ProfiOilPrice3ij $+\beta 4$ epsOilPrice $4 \mathrm{ij}+\beta 5$ Wor. kCapOilPrice $5 \mathrm{ij}+(\alpha \mathrm{i}+\mu \mathrm{ij})$

This model captures constant Auto-Covariance within panels. The adequacy of the model to explain a given relationship is very important. Breusch and Pagan lagrangian Multiplier is used for the selection of the most adequate model in explaining the relationship between company fundamentals and stock prices.

$$
\begin{aligned}
& \left.\begin{array}{rl}
L M & =\frac{N T}{2(T-1)}\left[\frac{\hat{\mathbf{e}}^{\prime}\left(\mathbf{J}_{T} \otimes \mathbf{I}_{N}\right) \hat{\mathbf{e}}}{\hat{\mathbf{e}}^{\prime} \hat{\mathbf{e}}}-1\right] \sim \chi^{2}(1) \\
& =\frac{N T}{2(T-1)}\left[\frac{\sum_{i=1}^{N}\left(\sum_{t=1}^{T} \hat{e}_{i t}\right)^{2}}{\sum_{i=1}^{N} \sum_{t=1}^{T} \hat{e}_{i t}^{2}}-1\right]
\end{array}\right]^{2} \\
& \text { where } \hat{e}_{i t}=y_{i t}-\left[\begin{array}{ll}
\mathbf{x}_{i t}^{\prime} & 1
\end{array}\right]\left[\begin{array}{l}
\hat{\boldsymbol{\beta}} \\
\hat{u}
\end{array}\right]_{\text {Pooled }}
\end{aligned}
$$


$\mathbf{L} \mathbf{M}$ is the Breusch and Pagan lagrangian Multiplier, $\boldsymbol{X}_{\mathbf{i t}}$ represent the exogenous variables (i.e. roa, reo, profit, eps, and work cap) of i company at $t$ time, $\hat{\mathbf{e}}$ is error term, $\mathbf{T}$ is the year $\mathrm{t}=1,2,3-\mathrm{T}, \mathbf{N}$ is the company $i=1,2$, 3-------N and êit is $y_{i t}-x_{i t} \beta$.

To ascertain no variables or group of variables have the same influence the study conducted the multi co-linearity test, thus;

$$
\text { V.I.F }=1 / \text { tolerance value, where tolerance value }=1-R_{j}{ }^{2}
$$

Where $\mathbf{R}_{\mathbf{j}}{ }^{2}$ is the coefficient of determination of regression of exogenous explanator $\mathbf{j}$ on all other explanators.

The study used Ramsey Reset Test to check the model whether any important variables (factors) are missing, given the following model;

IStockpricel =E \{stockpric|roaOilPrice, roeOilPrice, epsOilPrice, profitOilPrice, and workcapOilPrice $=\beta^{*} x$

\section{Results}

Data for five years period of the study were subjected to normality tests, using the Shapiro-Wilk $\mathrm{W}$ test for normal data. The null hypothesis $\left(\mathbf{H}_{\mathbf{o}}\right)$ stated that the data are not normally distributed. The results revealed the $Z$ value of average stock price, Return on Assets, Return on Equity, profit, earning per share, and working capital as $14.303,13.985,14.327,13.675,11.418$, and 11.084 respectively. This shows a significant value of $Z$, as such is a sign of abnormality of data. While the $|Z|$ is 0.0000 , which is significant at less than 1 percent. The null hypothesis is accepted. This normality test provides the premise and insight to subject the data to further test. The transformation could have been a way to correct the abnormality but the data were mixed up with negative integers, thus, taking the log or Lin may result in an error. The errors of this magnitude, however, do not affect the regression model. Since abnormality of data is mostly seen in the residual, then Robust regression could be used as an alternative. Consequently, pooled OLS, Simple, Fixed, or Random effect could be used.

From the appendix the expected mean value of the average stock price is N0.39, the minimum expected value is at $0 \mathrm{k}$, and the maximum expected value is $\mathrm{N} 45$. This revealed that the majority of the company sample have prices below N45. The Return on assets has a mean expected value of -0.004 times with a maximum of 3.24 times and a minimum expected value of -10.28 times. This implied that the majority of the sample company have ROA below 3.24times. Unlike ROA, ROE has a mean of 0.5 times, with a maximum of the expected value of 4.37 times, and a minimum of -235.29 times. Profit means is N7.662514 million, the minimum expected loss is -N20.73963 million and the maximum expected a profit of N21.37474 million. This revealed some companies suffer from serious losses while some companies make a huge profit. The expected mean of Earnings per share is N2.58433 with a minimum expected value $-\mathrm{N} 22.87$ and a maximum expected earnings per share of N180. The period under study across the cross-section exhibited serious problems with many companies incurring a loss in their operations. The expected mean value of working capital for the sample companies is N5.635438 million, the minimum expected value of working capital for the sample companies is -N21.66485 million, while the maximum expected value of working capital is N22.68855 million.

The result further revealed that the standard deviation of working Capital has the highest with N14.67884 million, follow by Profit with N12.41942. This indicated that the risk involves profit and working capital is high than any variable. ROA has the least variability with 0.5458711 times. ROE has a variation of 9.810325 times while earning per share has a deviation from the standard of 12.267 times.

The result of the correlation matrix test revealed that there is a weak association between endogenous variables and exogenous variables except for the association of EPS with Average stock prices and ROA with ROE which indicated a significant association of $51.68 \%$ and $78.38 \%$ respectively. The association of profit with an exogenous variable is $15.06 \%$, the correlation of earning per share ROA and ROE is $4.87 \%$ and $1.78 \%$ respectively. The association of working capital and the average stock price is $-8.75 \%$. This revealed that EPS moved with an average stock price more than any 
company fundamentals. ROA, ROE, Profit, and working capital have a weak association with average stock prices.

Table 1. The Regression Results

\begin{tabular}{|c|c|c|c|}
\hline & \multicolumn{3}{|c|}{$\begin{array}{l}\text { Dependent variable } \\
\text { Stock price }\end{array}$} \\
\hline & \multicolumn{3}{|r|}{ Models } \\
\hline Independent variables & Pooled-OLS & Fixed effect & Random effect \\
\hline $\begin{array}{l}\text { Return on Asset } \\
\text { (roa) }\end{array}$ & $\begin{array}{l}17.30992 \\
(0.39)\end{array}$ & $\begin{array}{c}-.1735231 \\
(-0.01)\end{array}$ & $\begin{array}{c}-2.888806 \\
(-0.14)\end{array}$ \\
\hline $\begin{array}{l}\text { Return on Equity } \\
\text { (roe) }\end{array}$ & $\begin{array}{c}-6.365949 \\
(-0.69)\end{array}$ & $\begin{array}{c}-1.41781 \\
(-0.32)\end{array}$ & $\begin{array}{c}-1.249278 \\
(-0.31)\end{array}$ \\
\hline $\begin{array}{c}\text { Earnings per share } \\
\text { (eps) }\end{array}$ & $\begin{array}{l}8.224383 \\
(7.18)^{* * *}\end{array}$ & $\begin{array}{c}-.0048141 \\
(-0.01)\end{array}$ & $\begin{array}{l}1.353135 \\
(2.25)^{* *}\end{array}$ \\
\hline $\begin{array}{l}\text { profit } \\
\text { (profit) }\end{array}$ & $\begin{array}{c}.738407 \\
(0.57)\end{array}$ & $\begin{array}{c}0.4175895 \\
(-0.85)\end{array}$ & $\begin{array}{c}-0.363516 \\
(-0.72)\end{array}$ \\
\hline $\begin{array}{c}\text { Working Capital } \\
\text { (Workcap) }\end{array}$ & $\begin{array}{c}-1.142026 \\
(-1.18)^{*} \\
\end{array}$ & $\begin{array}{c}.053293 \\
(1.33) \\
\end{array}$ & $\begin{array}{c}.4460818 \\
(1.07) \\
\end{array}$ \\
\hline $\begin{array}{c}\text { Oil Price } \\
(\text { Oil P })\end{array}$ & $\begin{array}{c}.1534521 \\
(0.56) \\
\end{array}$ & $\begin{array}{c}.1208634 \\
(1.21) \\
\end{array}$ & $\begin{array}{c}.1241808 \\
(1.19) \\
\end{array}$ \\
\hline $\begin{array}{c}\text { Roaoilprice } \\
\text { (Roa Oil Price) }\end{array}$ & $\begin{array}{c}-.0851426 \\
-0.17 \\
\end{array}$ & $\begin{array}{c}.053293 \\
(0.11) \\
\end{array}$ & $\begin{array}{c}.1052881 \\
(0.35) \\
\end{array}$ \\
\hline $\begin{array}{l}\text { Roe Oil price } \\
\text { (roeoil price) }\end{array}$ & $\begin{array}{c}.1123561 \\
(0.64) \\
\end{array}$ & $\begin{array}{c}.0271738 \\
(0.36) \\
\end{array}$ & $\begin{array}{c}.0251082 \\
(0.34) \\
\end{array}$ \\
\hline $\begin{array}{l}\text { Eps Oil Price } \\
\text { (epsoil.price) }\end{array}$ & $\begin{array}{c}-.0475183 \\
(-3.25) \\
\end{array}$ & $\begin{array}{c}.00625513 \\
(1.10) \\
\end{array}$ & $\begin{array}{c}-.001638 \\
(-0.28)\end{array}$ \\
\hline $\begin{array}{c}\text { Profit oil } \\
\text { (Prof. Oil price) } \\
\end{array}$ & $\begin{array}{c}.0006175 \\
(0.03) \\
\end{array}$ & $\begin{array}{c}.0061425 \\
(0.81) \\
\end{array}$ & $\begin{array}{c}.0060406 \\
(0.78) \\
\end{array}$ \\
\hline $\begin{array}{l}\text { Work Cap. Oil Price } \\
\text { (Work cap. Oil price) }\end{array}$ & $\begin{array}{c}.0013137 \\
(0.09) \\
\end{array}$ & $\begin{array}{c}-.0099642 \\
(-1.89) \\
\end{array}$ & $\begin{array}{c}-.0098286 \\
(-1.79) \\
\end{array}$ \\
\hline $\mathrm{R}^{2}$ & .3026 & 0.1544 & 0.2672 \\
\hline F- Statistic & $22.21^{* * *}$ & 1.41 & $31.14^{* * *}$ \\
\hline No of observation & 575 & 575 & 575 \\
\hline & $\mathrm{LM}(1)=$ & & \\
\hline
\end{tabular}

Source: Extract from the multiple regression test

The pooled- OLS model result revealed that chi $2(4)=22.21$ which is significant at lessthan1 percent. The pooled-OLS model is significant at less than 1 percent. This implied that the model is adequate at less than a 1 percent significant level to explain the relationship between company fundamentals and stock prices in Nigeria. The $Z$ values for Earning per share and working capital are significant at less than 1 percent, while ROA, ROE, and Profit are significant at 39.2 percent, 62.6 percent, and 1.7 percent respectively. The T-statistics of Earning per share is high. The coefficient of determination of the endogenous variable Profit is found below. While the coefficient of determination of ROA, ROE, EPS, and Working Capital is higher. These make us suspect the presence of multicolinearity in the model. When the oil price is added to all the variables the coefficients and T- statistics all change significantly. This is to admit the moderating influence of Oil price on the endogenous variables.

The model requires multi co-linearity Diagnostics test on the variables. This test would give the magnitude of the variance inflation factor (V.I.F) in the model. The test result exhibit high (V.I.F) for the stock price, ROA, ROE, profit, earning per share, and working capital. The mean V.I.F was found 
to be high. These test results are high. Using V.I.F to check the presence of multi-colinearity revealed that multicollinearity is present in the model.

Since there is a presence of multi-collinearity. There are no specific remedies for multi-co linearity, the major cause of multi-colinearity in the model is the repetition of Oil Price as a moderator. The study then tests whether some important variables are omitted in the model. To detect whether some important variables are omitted in the model, Ramsey Reset Test is required, using powers of the fitted values of the stock price. The Null Hypothesis $\left(\mathrm{H}_{\circ}\right)$ model has no omitted variables. The Ramsey Reset Test revealed $\mathrm{F}(3,568)=36.67$ and $\mathrm{P}>\mathrm{F}=0.000$. The $\mathrm{F}$ statistics are higher, and the $\mathrm{P}$-value is significant at less than 1 percent. The null hypothesis is accepted, and $\left(\mathrm{H}_{0}\right)$ holds that the model has no omitted variables.

The study took a more robust approach. A fixed-effect regression was run on 121 groups with 575 numbers observations. Thus, the test revealed $\mathrm{F}(4,443)=1.41$, the probability $>\mathrm{F}=0.1643$. From the overall results, the model was found to be inadequate to explain the relationship between company fundamentals and stock prices. The F statistics were found to be very low and the probability is greater than F statistics.

From a wider perspective, a random effect test was conducted on 121 groups of companies with 575 observations. The overall $\mathrm{R}^{2}$ was found to be 28.42 percent; Wald chi 2(5) value was 23.51 , the probability of chi 2 was found to be 0.0003 . This model was found to be significant at less than 1 percent; the Wald 2 (5) was also adequate to explain the relationship between the selected company fundamentals and stock prices.

To this end, the study faced with taking a course of action in determining the best model for that purpose, Breusch-Pagan Langregian Multiplier was employed given as: The Null hypothesis $\left(\mathbf{H}_{\mathbf{o}}\right)$ in $\mathrm{LM}$ test is that variances across entities are zero. That there is no significant difference across units (i.e. no panel effect). If no panel effect, then OLS or Pooled -OLS can be used. The result revealed chi 2 (1) value was found to be 764.15 and the probability of chi 2 was significant at less than 1 percent. The null hypothesis was rejected. The variances across entities are not zero; therefore, there is a panel effect. Therefore, pooled -OLS was not fit to explain the relationship between company fundamentals and stock price movements. The random effect regression model was found to be the most adequate model to explain the relationship between company fundamentals and stock prices.

The random effect regression model revealed that the model could not only explain 28.42 percent of the relationship between company fundamentals and stock prices. 71.58 percent of the relationship was explained by the model. This is statistically significant and econometrically adequate. The Fstatistic (Wald chi 2(4)) = 23.51 was also found to be significant at less than 1 percent significant level. This result revealed that there is a significant relationship between company fundamentals and stock prices. Since a relationship exist between company fundamentals and stock prices, and then company fundamentals have predictive power on stock prices. The joint contributions of the company fundamentals indicated that EPS has a higher influence of $2.25 \mathrm{t}$ - statistics. On the other hand, ROA, ROE, and Profit have an insignificant contribution with $t$ - statistics of $-0.14,-0.31$, and -0.72 respectively. Working capital has $1.07 \mathrm{t}$-statistics, which is also significant. The result indicated that EPS has a higher influence on stock price movements, followed by working capital. The test also revealed that ROA, ROE, and Profit have less influence on stock price movements.

When the relationship is moderated with Oil Price on the variables the $t$-statistics and Coefficient of determination changes substantially. This moderator (Oil Price) reduces the influence of EPS and Working Capital making t-statistic to fall to -0.28 and -1.79 which is insignificant and negatively significant respectively. The Coefficient of determination fall to -0.0001638 for EPS and -0.0098286 for Working Capital. ROA, ROE, and Profit all improved in their influences exerted on stock price movements when Oil prices acted as moderator. ROA, ROE, and Profit $t$-statistics changes to $0.35,0.34$, and 0.78 respectively. While the coefficient of determination changes to $0.1053,0.0251$, and 0.0060 accordingly.

\subsection{Discussion}


This study reaffirms the position held by Lam (2006), Fama \& French (2001), Shiller (2000), and Sivakumar \& Waymire (2000) where they find that the company's operating performance can explain a significant portion of stock price movements. The finding of Uddin \& Alan (2007) is in line with the finding of this study, where they found that company fundamentals have a significant positive relationship with share prices on the Dhaka Stock Exchange (DSE). This position is further reiterated by the findings of Milosevic \& Milenko (2017). From the random effect model, this study revealed that there exists a significant relationship between company fundamentals (specifically, earning per share and working capital) and stock price movements on NSE. The influence of each selected company fundamentals varies. This finding is also in line with the finding of Puspitaningtya (2017), From the random effect model, this study revealed that there exists a significant relationship between company fundamentals (specifically, earning per share and working capital) and stock price movements on NSE. The influence of each selected company fundamentals varies. This finding is also in line with the finding of Bahmani-Oskooee \& Sohrabian (1992). In a similar study, Yu (2003) applies the cointegration technique on daily stock price indices and company fundamentals obtained from the financial markets of Hong-Kong, Tokyo, and Singapore over the period from 1993 to 2003. He found that there is a possible interaction between company fundamentals and stock price. Jefferis \& Okeahalam (2000) work on South Africa, Botswana, Zimbabwe stock markets, where lower company fundamentals were hypothesized to depress stock prices. Arango (2002) finds some evidence of a linear and direct relationship between company fundamentals and share prices on Bogota's stock market. This result of this negates the finding of Lev (2001) where he finds that operating efficiency is not significantly related to contemporaneous stock price. The finding of this study contradicts the finding of Hsing (2004) when he uses a structural VAR model that allows for the simultaneous determination of company fundamentals found that an inverse relationship exists between company fundamentals and stock price. The study further attests to the findings of Rentschler (2013), Lahiani and Nguyen (2011) and, Shaharudin, Samad, and Bhat (2009) where they find that oil price moderates the influence of company fundamentals on stock price movements.

\section{Conclusions}

There exist a relationship between selected company fundamentals and stock prices in Nigeria. This relationship varies from one selected company fundamentals to another. The significant relationship of earnings per share resulted in the high predictive power of company fundamentals to stock price movements in Nigeria. Oil prices moderate the influence of company fundamentals on Stock price movements in Nigeria. Oil price relegates the influence of EPS and Working Capital, on other hand, it increases the influence of ROA, ROE, and Profit. The relationship of company fundamentals and stock prices in Nigeria does not go with that of New England or the U.S.A and in some instances, it does not oppose the argument of demand and supply of stock. The contribution, determination, and predictive power of the selected company fundamentals that are moderated by oil prices differ in Nigeria. The study recommends that Financial Analysts, Investors, and researchers alike should exert efforts to improve company fundamentals such as ROA, ROE, and Profit during oil prices increase since their influence increases. While earning per share and working capital when moderated by oil price their influence reduces stock price movements. This implies that the Financial Analyst, Economic Authorities, Investors, etc should recognize that the influence of ROA, ROE, and Profit on Stock price movements will be enhanced when moderated with oil prices. While the influence of Earning per share and working capital reduce on stock price movements when moderated by oil prices. this research received no external funding.

\section{References}

Abdulrasheed, H. \& Lokman, G. (2002). On the Causal Relationship between Stock Prices and Exchange Rates: Evidence from the MENA Region. Beykent University and University of Skovde Working paper No. 5, Istanbul, and Skovde. 
Arango, L.E., Gonzalez, A. \& Posada, C.E (2002). Returns and Interest rate: A nonlinear relationship in the Stock Market. Applied Financial Economics, 12(11), 835-842.

Arouri, M., Lahiani, A. \& Nguyen, D., K. (2011). Return and Volatility transmission between World Oil Prices and Stock Markets of the GCC Countries. Economic Modelling 28(4), 1815-1825.

A Zman-Saini, W.N., Habibullah, M.S., Lawsiong, H. \& Dayang- Afizzah, A.M (2006). Stock prices, exchange rates, and causality in Malaysia.

Bahmani-Oskooee, M. \& Sohrabian, A. (1992). Stock Prices and the Effective Exchange rate the dollar. Journal of Applied Economics (24), 459-464.

Ball, R. \& Brown, P. (1998). The Importance of Accounting Information in Portfolio Optimization. Journal of Accounting Research. (2) 128-150.

Ball, R. \& Brown, P. (2001). An empirical of accounting income numbers. Journal of Accounting Research. (6)159-178.

Bashir, T.M. (2015). Firm Performance and Stock Prices in Nigeria: A study of some selected Quoted Firms in the Nigerian Stock Exchange. Article published in the Ilorin Journal of Management Review. (2), 61-72.

Bashir, T.M. \& Mustapha, N. (2016). Firm Price -Earnings Ratio and Stock Prices: A Study of Quoted Firms in the Nigerian Stock Exchange. Article published in Sahel Analyst Journal of Management Sciences. (14),142-152.

Bulkley, E.J. \& Tonke, S. (2001). A Comparative Analysis of Stock Price Behavior and Investors Earning on Bombay, London, and New York Exchanges. Journal of Financial and Quantitative Analysis. 319 - 413.

Clark, K. (2013). What is the difference between the return on equity and return on capital?

Cleveland, D. (2012). The S\&P 500 Not overvalued, still undervalued Given ROA Strength of USA Corporates. Financial Review (3)5. Pp. 28-51.

Chang, C.Y. \& Wang, Y.M. (2008). A Study on the Technical Efficiency of Taiwan Commercial Banks. Asian- Pacific Economic and Management Review, 2(2). 23-48.

Chetty, R. Rosenberg, R. \& Saez, E. (2007). The Effects of Taxes on Market Responses to Dividend Announcements and Payments: what can we learn from the 2003 dividend tax cut Retrieved? International Monetary Fund (IMF) working paper (7), 204. European Department.

Dehuan, J. \& Zhenhu, J. (2008). Firm performance and Stock Returns An empirical study of the top-performing stock listed on the Shanghai Stock Exchange. Academy of Accounting and Financial Studies Journal 12 (1), 53-6.

Fama, E. (1970). Efficient Capital Markets: A review of theory and empirical work. The Journal of Finance Association, Wiley Online Library. 25 (2), 383-417.

Fama \& French (2002). Estimate the Equity Premium using Dividend Growth rates: Measure of the Expected Rate of Capital Gain. Journal of Applied Corporate Finance, Morgan Stanley.14 (1).67-79.

Filbeck, G.T., Krueger, M. \& Preece, D. (2007). CFO Magazine Working Capital Survey: Do selected firms Work for shareholders? Quarterly, Journal of Business Economics. 46 (2), 5-22.

Fisher, E.D. \& Jordan, R.J. (2003). Security Analysis and Portfolio Management.

Forte, A. (2000). Stock returns, real activity, inflation, and Money. American Economic Review, (71), 545-564.

Gompers, P.A.,Ishii, J. L. \& Metrick, A. (2003). Corporate Governance and Stock Price. Quarterly Journal of economics, Financial Institute Centre. 45(9), 234-255

Granger, C. W., Huang, B. \& Yang, C.W. (2000). A Bivariate Causality between Stock Prices and Exchange Rates: Evidence from the recent Asian flu" (unpublished).

Hansen, R. S. \& Crutchley, C. (2006). Corporate Earnings and Financing: An Empirical Analysis. Journal of Business (63), 347- 371.

Harasty, H. \& Roulet, J. (2000). Modeling Stock Market Returns. Journal of Portfolio Management, 26(2), 33.

Hennigar, E.S. \& Soenen, L.A. (2008). An Analysis of Exchange Rates and Stock Prices: the U.S. Experience between 1980 and 1986. Akron Business and Economic Review, (19), 1988, 7-16.

Higgin R. C. (2010). Analysis of Financial Management. McGraw Hill Publishers. $10^{\text {th }}$ Edition

Hsing, Y. (2004). Impacts of Fiscal Policy, Monetary Policy, and Exchange Rate Policy on Real GDP in Brazil: A VAR Model. Brazilian Electronic Journal of Economics, 6(1), 98 -121.

Kao, C. \& Chiang, M.-H. (2000). On the Estimation and Inference of a Cointegrated

Regression in Panel Data, in Baltagi B. H. (ed.), Advances in Econometrics: Non-stationary Panels, Panel Cointegration, and Dynamic Panels. (15), 179-222.

Keats, B.W., \& Hitt, M.A (2000). A Causal Model Linkages among Environmental Dimensions, Macro Organizational characteristic, and Performance. Academy of management journal, (3), 570-578.

Kpocke, R. W. (2000). Profits and Stock Prices: Importance of Being Earnest. New England Economic Review. (23) 124- 153.

Lam, O. (2003). Earnings and expected returns. Journal of finance. (5), 1563-1587. 
Lev., B. (2001). On the usefulness of earnings and earnings research: lessons and directions from two decades of empirical research. Journal of Accounting Research. 153-192.

Ling, M., John, W. \& Zhang, X., (2006). Specification Tests of International Asset Pricing Models. Journal of International Money and Finance (25), 275-307.

Loughran \& Ritter (2003). The new puzzle of stock price movements. Journal of Finance (50) 23-51.

Milosevic, S.A \& Milenko, I. (2017), Impact of Company performances on the Stock Price: Empirical analysis on selected companies in Serbia. Article published in advance in Economics, Business and Management Research, (40) 17-28.

Ohlson, F. (1995). The distinction between Earning and Dividend. Federal Reserve Bank Kansas City, Working paper.

Oliver, I. I (2015), Effect of Banks Financial Performance on Share Prices: Evidence from Nigerian Banking Industry (2004 - 2013). European Journal of Research and Reflection in Management Sciences. (3) 3, 69-79.

Pedroni, P. (2000), Panel Cointegration; Asymptotic and Finite Sample Properties of Pooled Time Series Tests, With an Application to the PPP Hypothesis. Working paper, Department of Economics, No. 95-013, Indiana University.

Pedroni, P. (2001). Critical values for cointegration tests in heterogeneous panels with multiple regressors, Oxford Bulletin of Economics and Statistics. (61), 653-670.

Puspitaningtyas, Z. (2017), Is Financial performance Reflected in Stock Price". Article published in advance in Economics, Business and Management Research, (40) 17-28.

Remi, S.A. (2005). Stock price and Earning per share: A sectoral analysis with panel data. Journal of Business and Economic Review, (3), 89-98.

Rentschler, J.E. (2013). Oil Price Volatility, Economic Growth, and the hedging role of Renewable Energy. Policy Research Working Paper Series 6603, The World Bank.

Richardson, E. (2000). The organization of industry. http://dx.doi.org/10.2307\%

Salami, H. (1999). Terms and their Conceptual meaning.

SEC committee reports of 2006.

SEC committee reports of 2007.

Shaharudin, R.S, Samad, F., Bhat, S. (2009). Performance and Volatility of Oil and Gas Stocks: A comparative study on selected Oil and Gas Companies. International Business Research 2(4) 87-99.

Sharma, S. (2009). Determinants of Equity Share Prices in India. World Research Journal of Art, Science, and Commerce. 11(4). 51- 60.

Shiller, R.J. (2000). Market Volatility.

Spyrou, I. S. (2001). Stock returns and inflation: evidence from an emerging market. Applied Economics Letters, 8.

Stavarek, D. (2004). Stock Prices and Exchange Rates in the EU and the USA: evidence their mutual interactions Silesian University School of Business Administration

Sivakumar, K. \& Waymire, G. (2000). The information content of earnings in a discretionary reporting environment: evidence from NYSE industrials, 1905-10. Journal of Accounting Research. 31 (1), 62-91.

Solnik, B. (2000). Using Financial prices to Test Exchange Rate Models: A note. A Journal of Finance, (42), 141-149.

$\mathrm{Su}, \mathrm{C}$., Chang, Y., Chen, Y. \& Ling, C. (2008). The relationship between Stock prices and EPS: Evidence-Based on Taiwan panel data. Economic Bulletin. (3), 1-12.

Uddin, M.G.S. \& Alam, M.M. (2007). The Impacts of Interest Rate on Stock Market: Empirical Evidence from Dhaka Stock Exchange. South Asian Journal of Management and Sciences, 1(2), 123-132.

Van Horne, J.C \& Wachowicz, J.M (2009). Fundamentals of financial management.

Yamane, T. (1967). Sampling Formula E-Book.

Yu, L. (2003). Capital Market Seasonality: The case of Stock Returns. Journal of Financial Economics. 3, 370-402.

Zanjidar, M. \& Sadri, P. (2012). The relationship between earnings per share forecast error and abnormal stock return of newly accepted corporation: Evidence from Iran's Capital Market. African Journal of Business Management. 6 (10), 3673-3681.

Zordan, D.J (2005). Stock prices, Interest Rates Investment Survival.

(C) 2020 by the authors. This article is an open-access article distributed under the terms and conditions of the Creative Commons Attribution (CC BY) license (http://creativecommons.org/licenses/by/4.0/). 